\title{
Concentration effects on the performance of bis(diimine) copper(I) dyes in dye-sensitized solar cells
}

\author{
Sven Y. Brauchli, Edwin C. Constable, * Catherine E. Housecroft* \\ Department of Chemistry, University of Basel, Spitalstrasse 51, 4056-Basel, Switzerland \\ Fax: +41 61267 1018; E-mail: catherine.housecroft@unibas.ch
}

\begin{abstract}
A critical factor that influences the performance of heteroleptic copper(I) bis(diimine) dyes in dye-sensitized solar cells (DSSCs) is shown to be the concentration of solution of the homoleptic copper(I) bis(diimine) complex used during the stepwise assembly of the dye on the semiconductor surface. The performance of the heteroleptic dye $[\mathrm{Cu}(\mathbf{1})(\mathbf{2})]^{+}(\mathbf{1}$ $=((6,6$ '-dimethyl-[2,2'-bipyridine]-4,4'-diyl)bis(4,1-phenylene $))$ bis(phosphonic acid); $2=$ 4,4'-(6,6'-dimethyl-[2,2'-bipyridine]-4,4'-diyl)bis(N,N-bis(4-methoxyphenyl)aniline) is investigated as a function of the concentration of $\left[\mathrm{Cu}(2)_{2}\right]\left[\mathrm{PF}_{6}\right]$ which undergoes ligand exchange with $\mathrm{TiO}_{2}$-anchored 1. With $0.1 \mathrm{mM}$ solutions of $\left[\mathrm{Cu}(2)_{2}\right]\left[\mathrm{PF}_{6}\right]$, optimal performance is reached on the day of fabricating the DSSC. Solar cells made using more concentrated solutions of $\left[\mathrm{Cu}(2)_{2}\right]\left[\mathrm{PF}_{6}\right]$ show a ripening effect and require increasing times (up to 4 days) to reach their optimal performance.
\end{abstract}

Keywords: copper; sensitizer; DSSC; dye concentration 


\section{Introduction}

The central component of a dye-sensitized solar cell (DSSC) is a coloured dye adsorbed on a semiconductor surface. In an n-type DSSC, the semiconductor is typically nanoparticulate $\mathrm{TiO}_{2}$ (anatase) and conventional dyes are ruthenium(II) complexes [1,2] or organic molecules [3]. In terms of sustainability and cost, it is expedient to develop dyes containing Earth-abundant metals from the first row of the d-block, e.g. copper, zinc and nickel, [4] in place of ruthenium. Of these, the most widely explored are dyes incorporating copper(I) which achieve photoconversion efficiencies (PCE) typically in the range of $2-3 \%[5,6,7,8,9]$. Recently, an impressive PCE of $4.66 \%$ was realized by combining a heteroleptic copper(I) dye containing a sterically hindered 6,6'-dimesityl2,2'-bipyridine-4,4'-dicarboxylic acid anchoring ligand and a 2,2'-bipyridine ancillary ligand bearing peripheral triphenylamino domains with the co-adsorbant chenodeoxycholic acid (cheno) [10].

In contrast to the strategy of the Odobel group in which heteroleptic copper(I) dyes are synthesised by the HETPHEN approach and subsequently anchored to the $\mathrm{TiO}_{2}$ surface $\left[{ }^{9},{ }^{10}\right]$, we have developed a stepwise assembly process in which the electrode is sequentially dipped into solutions of the anchoring ligand and then of a homoleptic complex $\left[\mathrm{Cu}\left(\mathrm{L}_{\text {ancillary }}\right)_{2}\right]\left[\mathrm{PF}_{6}\right]\left[{ }^{4}\right]$. In DSSC $\mathrm{s}$ in which an $\mathrm{I}^{-} / \mathrm{I}_{3}{ }^{-}$electrolyte is combined with copper(I)-containing dyes, a commonly observed phenomenon is for the efficiency of the DSSC to improve over a period of several days $\left[{ }^{8}, 11,12\right]$. This observation is reproduced when duplicate DSSC s are tested. This ripening effect has also been documented for ruthenium(II) dyes and is interpreted in terms of disaggregation and reorganization of the dye on the semi-conductor surface $[13,14,15]$. It is desirable that DSSCs exhibit their maximum performance immediately after assembly and retain this 
efficiency throughout their usable life-cycles. Most reports of copper(I) photosensitizers have focused on enhancing performance through structural modification of the dye. However, progress in this field will only be possible by more detailed investigations of other critical factors including the electrolyte [16,17], use of co-adsorbants [18] and solvent used in the dye bath [11].

We report here the effects of changing the concentration of the solution during the final step of dye assembly (Scheme 1). For adsorption of the standard dye N719, dye aggregation is prevented by using suitably dilute solutions, with concentrations $<0.4 \mathrm{mM}$ leading to the dye being adsorbed as monomers [14], but we are not aware of systematic studies of varying the concentration of copper(I)-based dyes. In this work, we use phosphonic acid 1 (Scheme 1) as the anchoring ligand; the incorporation of a phenylene spacer between the bpy and phosphonic acid units improves the performance of the $\left[\mathrm{Cu}\left(\mathrm{L}_{\text {anchor }}\right)\left(\mathrm{L}_{\text {ancillary }}\right)\right]^{+}$dye $\left[{ }^{8}\right]$. For the ancillary ligand, we selected 2 (Scheme 1$)$ which contains peripheral hole-transport triphenylamino-dendrons and is a promising candidate for incorporation into DSSCs $\left[{ }^{11}\right]$.

$<$ Scheme 1 to come here $>$

\section{Experimental}

\section{$2.1 \quad$ Chemicals}

Ligands $1\left[^{8}\right]$ and $2[11]$ and the complex $\left[\mathrm{Cu}(2)_{2}\right]\left[\mathrm{PF}_{6}\right][11]$ were prepared as previously described.

\subsection{DSSC fabrication}


DSSCs were prepared following a similar procedure to that detailed by Grätzel and coworkers $[19,20]$. Solaronix Test Cell Titania Electrodes were used for the photoanodes. These electrodes were washed with $\mathrm{EtOH}$ and sintered at $450^{\circ} \mathrm{C}$ for $30 \mathrm{~min}$, cooled to $\approx 80^{\circ} \mathrm{C}$, and then dipped into a $1 \mathrm{mM}$ DMSO solution of the anchoring ligand $\mathbf{1}$ for 1 day (24 h). The electrode was removed from the solution, washed with DMSO and EtOH and dried with a heat gun $\left(60^{\circ} \mathrm{C}\right)$. The functionalized electrode was then dipped into a 2.0, 1.0, 0.5 or $0.1 \mathrm{mM} \mathrm{MeCN}$ solution of $\left[\mathrm{Cu}(2)_{2}\right]\left[\mathrm{PF}_{6}\right]$ for 3 days. Each reference cell was prepared by dipping a commercial electrode (see above) in a $0.3 \mathrm{mM} \mathrm{EtOH}$ solution of standard dye N719 (Solaronix) for 3 days. After the dipping period, each electrode was washed with the same solvent used in the dipping process and dried at $60{ }^{\circ} \mathrm{C}$ (heat gun). Solaronix Test Cell Platinum Electrodes were used for the photocathodes, and any volatile organic impurities were removed by heating for $30 \mathrm{~min}$ at $450{ }^{\circ} \mathrm{C}$ (heating plate).

The dye-covered $\mathrm{TiO}_{2}$ electrode and $\mathrm{Pt}$ counter electrode were assembled using thermoplast hot-melt sealing foil (Solaronix Test Cell Gaskets) by heating while pressing them together. The electrolyte was introduced into the DSSC by vacuum backfilling and comprised LiI $\left(0.1 \mathrm{~mol} \mathrm{dm}^{-3}\right), \mathrm{I}_{2}\left(0.05 \mathrm{~mol} \mathrm{dm}^{-3}\right), 1-$ methylbenzimidazole $\left(0.5 \mathrm{~mol} \mathrm{dm}^{-3}\right)$ and 1-butyl-3-methylimidazolinium iodide $\left(0.6 \mathrm{~mol} \mathrm{dm}^{-3}\right)$ in 3-methoxypropionitrile. The hole in the counter electrode was sealed using hot-melt sealing foil (Solaronix Test Cell Sealings) and a cover glass (Solaronix Test Cell Caps).

\subsection{DSSC and external quantum efficiency (EQE) measurements}

The solar cell measurements and testing protocol was performed using fully masked cells. A black coloured copper sheet was used for masking with a single aperture of average area $0.06012 \mathrm{~cm}^{2}$ (standard deviation of $1 \%$ ) placed over the dye-sensitized $\mathrm{TiO}_{2}$ circle. The area of the aperture in the mask was smaller than the active area of the $\mathrm{TiO}_{2}(0.36$ 
$\mathrm{cm}^{2}$ ). For complete masking, tape was also applied over the edges and rear of cell. Measurements were made by irradiating from behind using as a light source a SolarSim 150 instrument $\left(100 \mathrm{~mW} \mathrm{~cm}^{-2}=1 \mathrm{sun}\right)$. The power of the simulated light was calibrated by using a silicon reference cell.

The external quantum efficiency (EQE) measurements were performed on a SpeQuest quantum efficiency setup from Rera Systems (Netherlands) equipped with a $100 \mathrm{~W}$ halogen lamp (QTH) and a lambda 300 grating monochromator from Lot Oriel. The monochromatic light was modulated to $3 \mathrm{~Hz}$ using a chopper wheel from ThorLabs. The cell response was amplified with a large dynamic range IV converter from CVI Melles Griot and then measured with a SR830 DSP Lock-In amplifier from Stanford Research.

\section{$3 \quad$ Results and discussion}

\subsection{J-V characteristics and efficiencies of DSSCs using different concentrations of} $\left[\mathrm{Cu}(2)_{2}\right][\mathrm{PF} 6]$

The strategy shown in Scheme 1 was used to assemble the heteroleptic copper(I) dye anchored to the photoanode. Phosphonic acid 1 was adsorbed onto the $\mathrm{TiO}_{2} / \mathrm{FTO}$-coated glass plate and the electrode was left in the DMSO solution of $\mathbf{1}$ for one day. In the second step in Scheme 1, the functionalized electrode was immersed in an $\mathrm{MeCN}$ solution of the homoleptic complex $\left[\mathrm{Cu}(2)_{2}\right]\left[\mathrm{PF}_{6}\right]$ for 3 days, and concentrations of these solutions ranged from 0.1 to $2.0 \mathrm{mM}$. An $\mathrm{I}_{3}{ }^{-} / \mathrm{I}^{-}$electrolyte was used and fully masked DSSCs [21] were fabricated along with a reference DSSC containing standard dye N719 (Scheme 2). Measurements were made on the day of sealing the cells (day 0), and one, two and three days afterwards, and the performance data of the DSSCs are summarized in Table 1. The final column in Table 1 gives a relative efficiency with respect to N719 set to an arbitrary $100 \%$ [22]. The trends in the overall efficiencies $(\eta)$ are summarized in 
Figure 1. Figure 2 shows the $J-V$ curves for the DSSCs; all DSSCs exhibit good fill factors of $72-74 \%$.

$<$ Scheme 2 to come here $>$

$<$ Figure 1 to come here $>$

$<$ Table 1 to come here $>$

On the initial day, the highest efficiency $(\eta=1.61 \%$ with respect to $8.15 \%$ for $\mathrm{N} 719)$ is observed for the dye assembled using the most dilute solution of $\left[\mathrm{Cu}(\mathbf{2})_{2}\right]\left[\mathrm{PF}_{6}\right]$ $(0.1 \mathrm{mM})$. The more dilute the solution of $\left[\mathrm{Cu}(2)_{2}\right]\left[\mathrm{PF}_{6}\right]$ is, the higher the value of $\eta$ for the $[\mathrm{Cu}(\mathbf{1})(\mathbf{2})]^{+}$dye, and this correlates with a higher current density $\left(J_{\mathrm{SC}}\right)$. In contrast, the highest $V_{\mathrm{OC}}$ was observed with the most concentrated $\left[\mathrm{Cu}(2)_{2}\right]\left[\mathrm{PF}_{6}\right]$ solution.

Figure 1 illustrates that the DSSC containing the $[\mathrm{Cu}(\mathbf{1})(\mathbf{2})]^{+}$dye made with the lowest concentration of $\left[\mathrm{Cu}(2)_{2}\right]\left[\mathrm{PF}_{6}\right]$ exhibits a near constant efficiency over the four day period, consistent with the attainment of an optimal $J_{\mathrm{SC}}$ immediately after sealing the cells (Figures 1 and 3 ). In contrast, the $[\mathrm{Cu}(\mathbf{1})(\mathbf{2})]^{+}$dyes assembled using $2.0,1.0$ and 0.5 $\mathrm{mM}$ dye solutions of $\left[\mathrm{Cu}(2)_{2}\right]\left[\mathrm{PF}_{6}\right]$ show ripening effects with enhanced $J_{\mathrm{SC}}$ leading to improved $\eta$. Figure 3 shows that the enhancement in $J_{\mathrm{SC}}$ (and thus in $\eta$, Figure 1) over time depends on the concentration of $\left[\mathrm{Cu}(2)_{2}\right]\left[\mathrm{PF}_{6}\right]$ in the dye bath. The most pronounced increase in efficiency occurs for the device prepared using the most concentrated $(2.0$ $\mathrm{mM}$ ) solution for which $J_{\mathrm{SC}}$ increases from 2.10 to $3.83 \mathrm{~mA} \mathrm{~cm}^{-2-}$ and $\eta$ from 0.81 to 1.49 $\%$ from day 0 to day 3 . Figure 3 illustrates that the time required for an optimal $J_{\mathrm{SC}}$ to be attained is directly related to the concentration of $\left[\mathrm{Cu}(2)_{2}\right]\left[\mathrm{PF}_{6}\right]$, and these results are consistent with aggregation of dye molecules when the concentration of $\left[\mathrm{Cu}(2)_{2}\right]\left[\mathrm{PF}_{6}\right]$ is 
$\geq 0.5 \mathrm{mM}$. The most important factor contributing to the immediate peak performance of the DSSC made with the $0.1 \mathrm{mM}$ solution of the homoleptic complex is the attainment of an optimum $J_{\mathrm{SC}}$ on the initial day (Figure 3). Figure 3 also shows that the final $J_{\mathrm{SC}}$ is directly affected by the concentration of the homoleptic complex.

$<$ Figures 2 and 3 near here $>$

\subsection{EQE spectra}

The EQE spectra in Figure 4 represent the evolution in $J_{\mathrm{SC}}$ over time. All cells exhibit a similar curve shape with a $\lambda_{\max }=470 \mathrm{~nm}$. On the day of DSSC fabrication, the highest and lowest EQEs $(\approx 25 \%$ and $15 \%)$ were obtained for the devices prepared using the most dilute $(0.1 \mathrm{mM})$ and most concentrated $(2.0 \mathrm{mM})$ solutions of $\left[\mathrm{Cu}(2)_{2}\right]\left[\mathrm{PF}_{6}\right]$, respectively. Figure 4 illustrates that a significant enhancement in $\mathrm{EQE}_{\max }$ is observed for the DSSC made using the most concentrated solution of homoleptic complex, and that the improvement in $\mathrm{EQE}_{\max }$ is less the more dilute the solution becomes. For the dye assembled using the $0.1 \mathrm{mM}$ solution, optimum $\mathrm{EQE}_{\max }$ is achieved immediately.

$<$ Figure 4 here $>$

\section{Conclusions}

To date, studies of simple factors that affect the performance of DSSCs containing copper(I)-based sensitizers have been few. An established protocol for assembling heteroleptic copper(I) bis(diimine) dyes on $\mathrm{T} \mathrm{TiO}_{2}$ surface inolves ligand exhange 
between an anchored diimine ligand and a homoleptic $\left[\mathrm{Cu}\left(\mathrm{L}_{\text {ancillary }}\right)_{2}\right]^{+}$complex. In this work, we have established that the concentration of $\left[\mathrm{Cu}\left(\mathrm{L}_{\text {ancillary }}\right)_{2}\right]^{+}$has a profound influence upon the rate at which an optimum $J_{\mathrm{SC}}$ is attained and on the actual value of $J_{\text {SC }}$ This necessarily impacts upon the global efficiency of the DSSCs. Coupled with the use of a $1 \mathrm{mM}$ DMSO solution of anchoring ligand 1, the best performing solar cells are achieved using a $0.1 \mathrm{mM} \mathrm{MeCN}$ solution of $\left[\mathrm{Cu}(2)_{2}\right]\left[\mathrm{PF}_{6}\right]$. Although DSSCs made with a $0.5 \mathrm{mM}$ solution ultimately perform with a similar efficiency, there is a delay of two days before optimum performance is observed.

\section{Acknowledgements}

We gratefully acknowldge the European Research Council (Advanced Grant 267816 LiLo), the Swiss National Science Foundation, and the University of Basel for financial support. We thank Dr Biljana Bozic-Weber and Sebastian Fürer for helpful discussions.

\section{References}

[1] M. Grätzel, Solar Energy Conversion by Dye-Sensitized Photovoltaic Cells, Inorg. Chem. 44 (2005) 6841-6851.

[2] A. Reynal, E. Palomares, Ruthenium Polypyridyl Sensitisers in Dye Solar Cells Based on Mesoporous $\mathrm{TiO}_{2}$, Eur. J. Inorg. Chem. (2011) 4509-4526.

[3] A. Mishra, M. K. R. Fischer, P. Bäuerle, Metal-Free Organic Dyes for DyeSensitized Solar Cells: From Structure: Property Relationships to Design Rules, Angew. Chem. Int. Ed. 48 (2009) 2474-2499. 
[4] B. Bozic-Weber, E. C. Constable, C. E. Housecroft, Light harvesting with Earth abundant $d$-block metals: towards a sustainable materials chemistry, Coord. Chem. Rev. 257 (2013) 3089-3106.

[5] T. E. Hewat, L. J. Yellowlees, N.Robertson, Neutral copper(I) dipyrrin complexes and their use as sensitizers in dye-sensitized solar cells, Dalton Trans. 43 (2014) $4127-4136$.

[6] K. A. Wills, H. J. Mandujano-Ramírez, G. Merino, D. Mattia, T. Hewat, N. Robertson, G. Oskam, M. D. Jones, S. E. Lewis, P. J. Cameron, Investigation of a copper(I) biquinoline complex for application in dye-sensitized solar cells, RSC Adv. 3 (2013) 23361-23369.

[7] A. Colombo, C. Dragonetti, D. Roberto, A. Valore, P. Biagini, F. Melchiorre, A simple copper(I) complex and its application in efficient dye-sensitized solar cells Inorg. Chim. Acta 407 (2013) 204-209.

[8] B. Bozic-Weber, S. Y. Brauchli, E. C. Constable, S. O. Fürer, C. E. Housecroft, F. J. Malzner, I. A. Wright, J. A. Zampese, Improving the photoresponse of copper(I) dyes in dye-sensitized solar cells by tuning ancillary and anchoring ligand modules, Dalton Trans. 42 (2013) 12293-12308.

[9] M. Sandroni, M. Kayanuma, A. Planchat, N. Szuwarski, E. Blart, Y. Pellegrin, C. Daniel, M. Boujtita, F. Odobel, First application of the HETPHEN concept to new heteroleptic bis(diimine) copper(I) complexes as sensitizers in dye sensitized solar cells, Dalton Trans. 42 (2013) 10818-10827.

[10] M. Sandroni, L. Favereau, A. Planchat, H. Akdas-Kilig, N. Szuwarski, Y. Pellegrin, E. Blart, H. Le Bozec, M. Boujtita, F. Odobel, Heteroleptic copper(I) 
polypyridine complexes as efficient sensitizers for dye sensitized solar cells, J. Mater. Chem. A 2 (2014) 9944-9947.

[11] B. Bozic-Weber, S. Y. Brauchli, E. C. Constable, S. O. Fürer, C. E. Housecroft, I. A. Wright, Hole-transport functionalized copper(I) dye sensitized solar cells, Phys. Chem. Chem. Phys. 15 (2013) 4500-4504.

[12] B. Bozic-Weber, V. Chaurin, E. C. Constable, C. E. Housecroft, M. Meuwly, M. Neuburger, J. A. Rudd, E. Schönhofer, L. Siegfried, Exploring copper(I)-based dye-sensitized solar cells: a complementary experimental and TD-DFT investigation, Dalton Trans. 41 (2012) 14157-141169.

[13] B. Wenger, M. Grätzel, J.-E. Moser, Rationale for kinetic heterogeneity of ultrafast light-induced electron transfer from $\mathrm{Ru}(\mathrm{II})$ complex sensitizers to nanocrystaline $\mathrm{TiO}_{2}$, J. Am. Chem. Soc. 127 (2005) 12150-12151.

[14] B. Wenger, M. Grätzel, J.-E. Moser, Origin of the kinetic heterogeneity of ultrafast light-induced electron transfer from $\mathrm{Ru}(\mathrm{II})$-complex dyes to nanocrystaline semiconducting particles, Chimia 59 (2005) 123-125.

[15] V. K. Thorsmølle, B. Wenger, J. Teuscher, C. Bauer, J.-E. Moser, Dynamics of photoinduced interfacial electron transfer and charge transport in dye-sensitized mesoscopic semiconductors, Chimia 61 (2007) 631-634.

[16] B. Bozic-Weber, E. C. Constable, S. O. Fürer, C. E. Housecroft, L. J. Troxler and J. A. Zampese, Copper(I) dye-sensitized solar cells with $\left[\mathrm{Co}(\mathrm{bpy})_{3}\right]^{2+/ 3+}$ electrolyte, Chem. Commun. 49 (2013) 7222-7224.

[17] L. N. Ashbrook, C. M. Elliott, Dye-sensitized solar cell studies of a donorappended bis(2,9-dimethyl-1,10-phenthroline) $\mathrm{Cu}(\mathrm{I})$ dye paired with a cobalt-based mediator, J. Phys. Chem. C 117 (2013) 3853-3864. 
[18] C. L. Linfoot, P. Richardson, T. E. Hewat, P. Moudam, M. M. Forde, A. Collins, F. White, N. Robertson, Substituted [Cu(I)(POP)(bipyridyl)] and related complexes: synthesis, structure, properties and application to dye-sensitized solar cells, Dalton Trans. 39 (2010) 8945-8956.

[19] S. Ito, T. N. Murakami, P. Comte, P. Liska, C. Grätzel, M. K. Nazeeruddin, M. Grätzel, Fabrication of thin film dye sensitized solar cells with solar to electric power conversion efficiency over 10\%, Thin Solid Films 516 (2008) 4613-4619.

[20] S. Ito, P. Chen, P. Comte, M. K. Nazeeruddin, P. Liska, P. Péchy, M. Grätzel, Fabrication of screen-printing pastes from $\mathrm{TiO}_{2}$ powders for dye-sensitised solar cells, Prog. Photovoltaics Res. Appl. 15 (2007) 603-612.

[21] H. J. Snaith, How should you measure your excitonic cells? Energy Envir. Sci. 5 (2012) 6513.

[22] F. J. Malzner, S. Y. Brauchli, E. Schönhofer, E. C. Constable and C. E. Housecroft, To deprotect or not to deprotect: phosphonate ester versus phosphonic acid anchor ligands in copper(I)-based dye-sensitized solar cells, Polyhedron (2014) doi: 10.1016/j.poly.2014.05.019. 
Table 1 Performances of masked DSSCs using the dye $[\mathrm{Cu}(\mathbf{1})(\mathbf{2})]^{+}$and different concentrations of $\left[\mathrm{Cu}(\mathbf{2})_{2}\right]\left[\mathrm{PF}_{6}\right]$ in step 2 shown in Scheme 1. The dipping time for initial adsorption of 1 was 1 day and was 3 days for ligand exchange.

\begin{tabular}{|c|c|c|c|c|c|c|c|}
\hline Dye & $\begin{array}{c}\text { Conc. } \\
\text { of } \\
{\left[\mathrm{Cu}(2)_{2}\right]^{+}} \\
/ \mathrm{mM}\end{array}$ & $\begin{array}{c}\text { Day of } \\
\text { measurement }^{\mathrm{a}}\end{array}$ & $\begin{array}{c}J_{s c} \\
/ \mathrm{mA} / \mathrm{cm}^{2}\end{array}$ & $\begin{array}{c}V_{o c} \\
/ \mathrm{mV}\end{array}$ & $\begin{array}{l}f f \\
/ \%\end{array}$ & $\begin{array}{c}\eta \\
/ \%\end{array}$ & $\begin{array}{c}\text { Relative } \\
\eta \\
/ \%\end{array}$ \\
\hline$[\mathrm{Cu}(\mathbf{1})(\mathbf{2})]^{+}$ & 2.0 & 0 & 2.10 & 535 & 72 & 0.81 & 10.0 \\
\hline$[\mathrm{Cu}(\mathbf{1})(\mathbf{2})]^{+}$ & 1.0 & 0 & 3.24 & 511 & 73 & 1.21 & 14.9 \\
\hline$[\mathrm{Cu}(\mathbf{1})(\mathbf{2})]^{+}$ & 0.5 & 0 & 4.09 & 501 & 73 & 1.51 & 18.5 \\
\hline$[\mathrm{Cu}(\mathbf{1})(\mathbf{2})]^{+}$ & 0.1 & 0 & 4.55 & 489 & 72 & 1.61 & 19.7 \\
\hline N719 & 0.3 & 0 & 17.47 & 641 & 73 & 8.15 & 100.0 \\
\hline$[\mathrm{Cu}(\mathbf{1})(\mathbf{2})]^{+}$ & 2.0 & 1 & 3.69 & 531 & 73 & 1.44 & 17.0 \\
\hline$[\mathrm{Cu}(\mathbf{1})(\mathbf{2})]^{+}$ & 1.0 & 1 & 3.93 & 507 & 73 & 1.46 & 17.3 \\
\hline$[\mathrm{Cu}(\mathbf{1})(\mathbf{2})]^{+}$ & 0.5 & 1 & 4.29 & 503 & 73 & 1.59 & 18.8 \\
\hline$[\mathrm{Cu}(\mathbf{1})(\mathbf{2})]^{+}$ & 0.1 & 1 & 4.48 & 485 & 72 & 1.57 & 18.6 \\
\hline N719 & 0.3 & 1 & 17.45 & 663 & 73 & 8.45 & 100.0 \\
\hline$[\mathrm{Cu}(\mathbf{1})(\mathbf{2})]^{+}$ & 2.0 & 2 & 3.67 & 516 & 73 & 1.39 & 16.9 \\
\hline$[\mathrm{Cu}(\mathbf{1})(\mathbf{2})]^{+}$ & 1.0 & 2 & 3.90 & 503 & 73 & 1.44 & 17.5 \\
\hline$[\mathrm{Cu}(\mathbf{1})(\mathbf{2})]^{+}$ & 0.5 & 2 & 4.37 & 509 & 73 & 1.63 & 19.9 \\
\hline$[\mathrm{Cu}(\mathbf{1})(\mathbf{2})]^{+}$ & 0.1 & 2 & 4.57 & 494 & 72 & 1.62 & 19.7 \\
\hline N719 & 0.3 & 2 & 17.05 & 664 & 73 & 8.22 & 100.0 \\
\hline$[\mathrm{Cu}(\mathbf{1})(\mathbf{2})]^{+}$ & 2.0 & 3 & 3.83 & 528 & 73 & 1.49 & 18.2 \\
\hline$[\mathrm{Cu}(\mathbf{1})(\mathbf{2})]^{+}$ & 1.0 & 3 & 4.02 & 508 & 74 & 1.51 & 18.4 \\
\hline$[\mathrm{Cu}(\mathbf{1})(\mathbf{2})]^{+}$ & 0.5 & 3 & 4.36 & 508 & 73 & 1.63 & 19.9 \\
\hline$[\mathrm{Cu}(\mathbf{1})(\mathbf{2})]^{+}$ & 0.1 & 3 & 4.56 & 492 & 72 & 1.61 & 19.7 \\
\hline N719 & 0.3 & 3 & 17.02 & 665 & 72 & 8.19 & 100.0 \\
\hline
\end{tabular}

${ }^{a}$ Day $0=$ Day of DSSC fabrication 


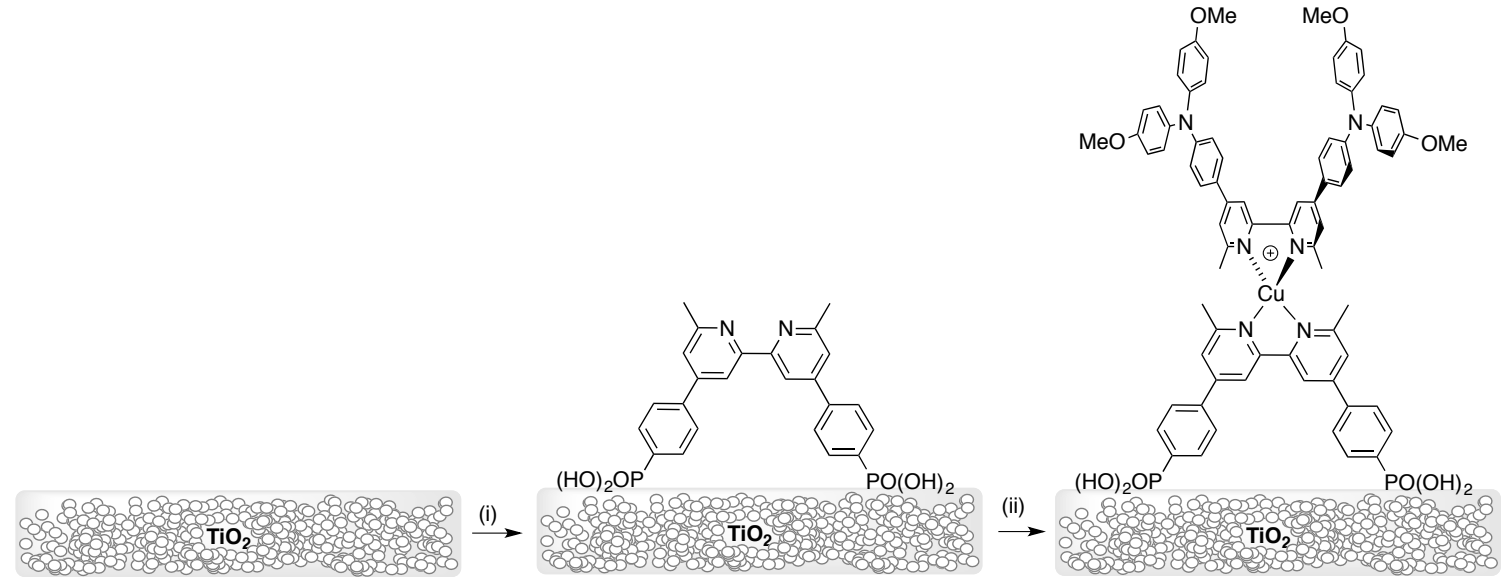

Scheme 1.

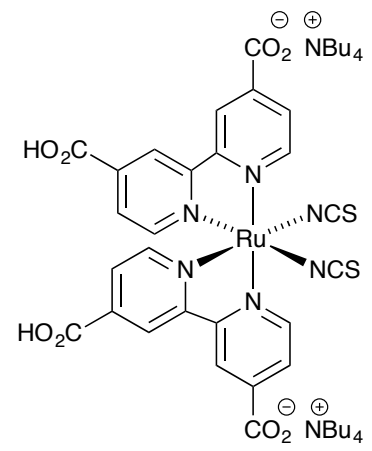

N719

Scheme 2. 


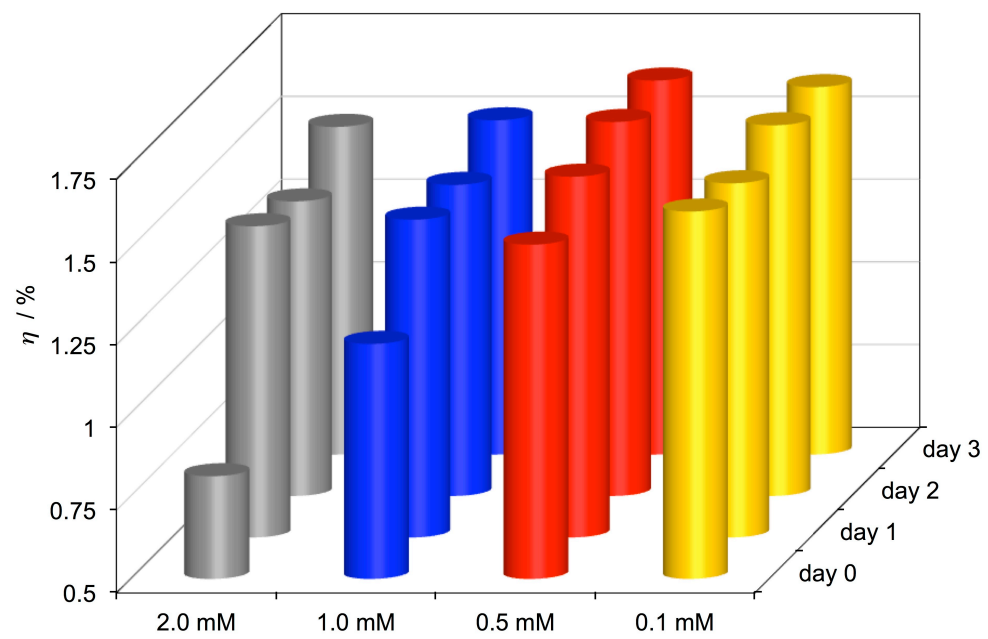

Figure 1.

- $[\mathrm{Cu}(1)(2)]+2.0 \mathrm{mM}$ Day 0

- $[\mathrm{Cu}(1)(2)]+1.0 \mathrm{mM}$ Day 0

---[Cu(1)(2)]+ $2.0 \mathrm{mM}$ Day 3

---[Cu(1)(2)]+ $0.5 \mathrm{mM}$ Day 3

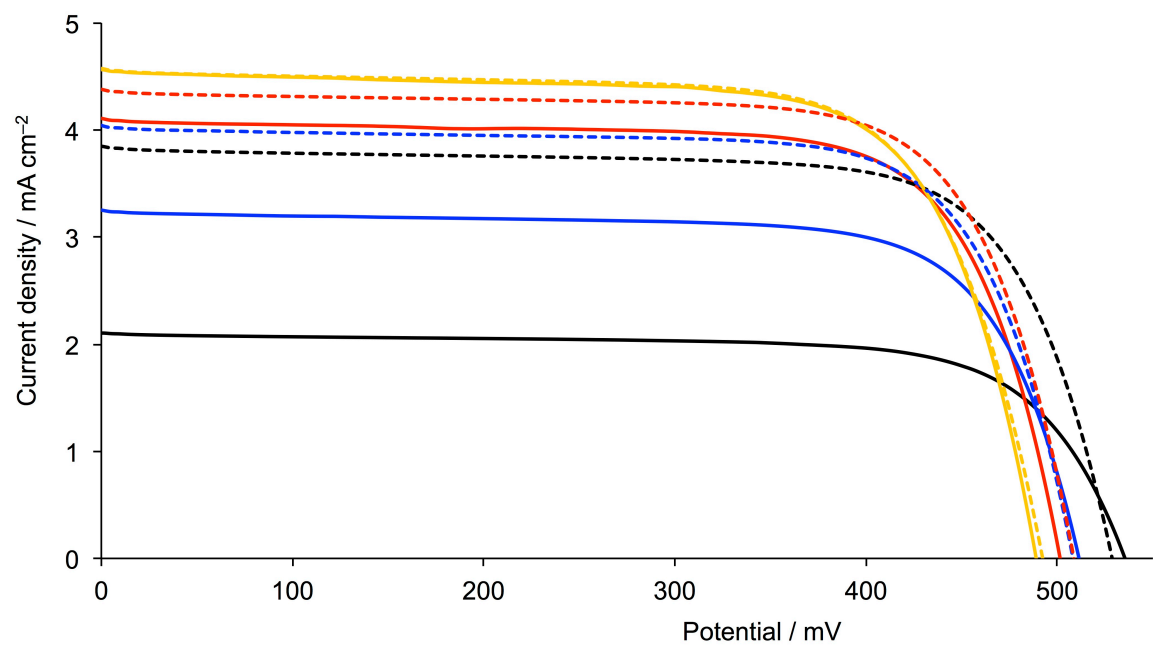

- $[\mathrm{Cu}(1)(2)]+0.5 \mathrm{mM}$ Day 0

- $[\mathrm{Cu}(1)(2)]+0.1 \mathrm{mM}$ Day 0

--[Cu(1)(2)]+ $1.0 \mathrm{mM}$ Day 3

$--[\mathrm{Cu}(1)(2)]+0.1 \mathrm{mM}$ Day 3

Figure 2 


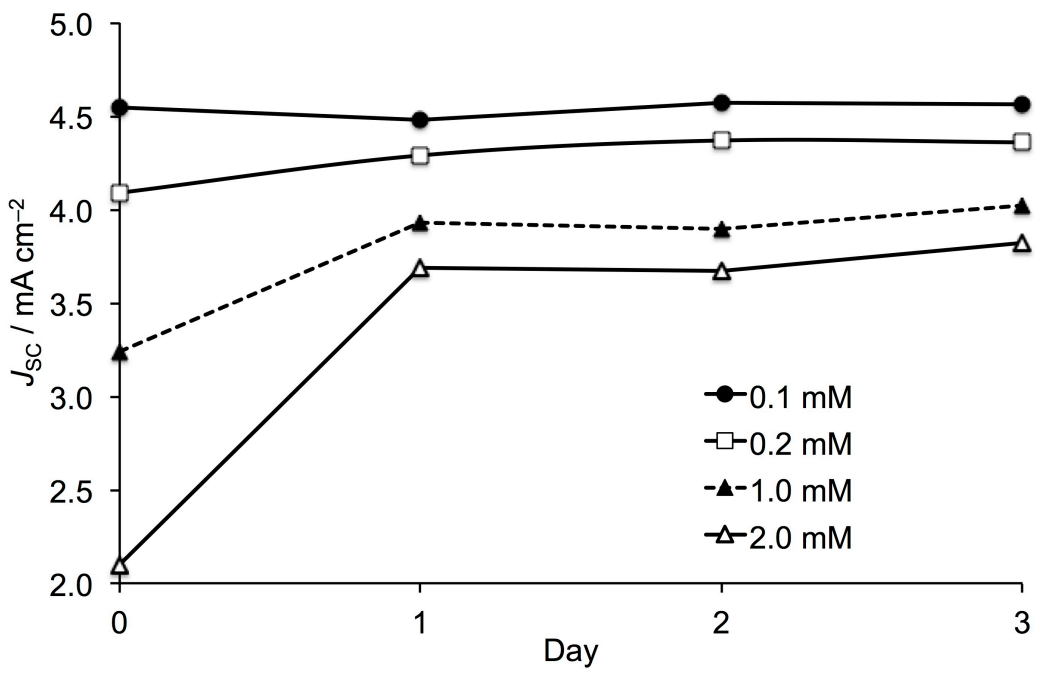

Figure 3.

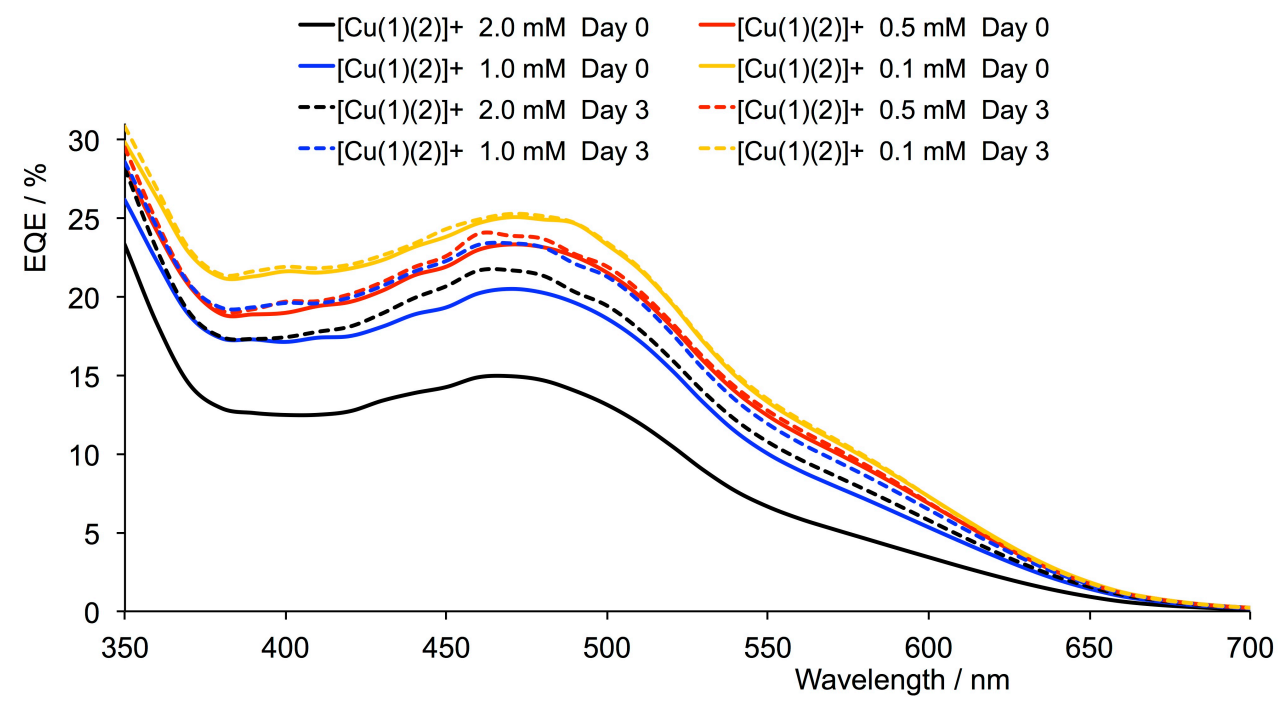

Figure 4. 
Figure captions

Scheme 1. Strategy for the assembly of the dye $[\mathrm{Cu}(\mathbf{1})(2)]^{+}$. (i) $1 \mathrm{mM}$ DMSO solution of anchoring ligand 1, 1 day; (ii) 2.0, 1.0, 0.5 or $0.1 \mathrm{mM} \mathrm{MeCN}$ solution of $\left[\mathrm{Cu}(\mathbf{2})_{2}\right]\left[\mathrm{PF}_{6}\right](\mathbf{2}$ $=$ ancillary ligand), 3 days.

Scheme 2. The structure of standard dye N719.

Figure 1. 3D-bar diagram showing the changes in global efficiencies $(\eta)$ over time (day 0 to day 3) as a function of concentration of $\left[\mathrm{Cu}(2)_{2}\right]\left[\mathrm{PF}_{6}\right]$ in the dipping process. Data correspond to Table 1. (Colour online.)

Figure 2. Current density $\left(J_{\mathrm{SC}}\right)$-potential $\left(V_{\mathrm{OC}}\right)$ plots for DSSCs containing the dye $[\mathrm{Cu}(\mathbf{1})(\mathbf{2})]^{+}$and made using different concentrations of $\left[\mathrm{Cu}(\mathbf{2})_{2}\right]\left[\mathrm{PF}_{6}\right]$ (see Scheme 1). Data correspond to Table 1. (Colour online.)

Figure 3. Changes in current density $\left(J_{\mathrm{SC}}\right)$ over time; day $0=$ day of sealing the DSSC. Concentrations refer to the $\mathrm{MeCN}$ solution of $\left[\mathrm{Cu}(2)_{2}\right]\left[\mathrm{PF}_{6}\right]$.

Figure 4. EQE spectra for DSSCs containing the dye $[\mathrm{Cu}(\mathbf{1})(\mathbf{2})]^{+}$and made using different concentrations of $\left[\mathrm{Cu}(2)_{2}\right]\left[\mathrm{PF}_{6}\right]$ (see Scheme 1). Data correspond to the DSSCs in Table 1. (Colour online.) 
